\title{
A PETŐ INTÉZET INTEGRÁCIÓT SEGÍTŐ MINDENNAPOS TEVÉKENYSÉGE ITTHON ÉS KÜLFÖLDÖN
}

Szerző:

Oravecz Adrienn

Eszterházy Károly Főiskola

Szerző e-mail címe:

ora_adri@msnn.com
Lektorok:

Estefánné Varga Magdolna

Eszterházy Károly Főiskola

Dávid Mária

Eszterházy Károly Főiskola

Mező Katalin

Debreceni Egyetem

Schéder Veronika

Debreceni Egyetem

Oravecz Adrienn (2015): A Pető Intézet Integrációt segítő mindennapos tevékenysége itthon és külföldön, Különleges Bánásmód, I. évf. 2015/4. szám, 49-64. DOI 10.18458/KB.2015.4.49

\begin{abstract}
Absztrakt
E tanulmány Petö Andrást „a konduktív pedagógia atyját”, módszerét és intézetét mutatja be. Új rehabilitációs módszere lehetöséget adott a mozgássérült gyermekek és felnöttek számára megtanulni, hogy a fizikai sérülések ellenére miként lehet beillszkedni a társadalomba és megküzdeni a mindennapi kihívásokkal. Intézetét 1945-ben, a második világháborút követöen alapította meg. Az intézetet róla nevezték el, s vált az országosan és nemzetközileg jól ismert Petö Intézetté.
\end{abstract}

Kulcsszavak: Pető András, Pető Módszer, Konduktív pedagógia, Integráció

Diszciplína: Gyógypedagógia

\begin{abstract}
EVERYDAY ACTIVITIES TO HELP INTEGRATION IN PETHÖ INSTITUTE IN HUNGARY $A N D A B R O A D$

This paper will present András Petö, the father of the conductive pedagogy, his method and his institute. His new rehabilitation method gave a chance to motor disordered children and adults to learn how to adjust into the society and cope with daily challenges in spite of their physical disadvantage. He established his institute after World War II in 1945, and the institute was named after him and became nationally and internationally well-known as Petö Institute.
\end{abstract}

Keywords: András Pető, Pető Methood, Conductive Education, Integration

Discipline: Special education 
KÜLÖNLEGES BÁNÁSMÓD, I. ÉVF. 2015/4.

\section{Pető András életútja}

Pető András 1893. szeptember 11.-én született Szombathelyen. Középiskolai tanulmányait a szombathelyi premontrei gimnáziumban végezte. Bécsbe ment orvoslást tanulni. Majd a grinzingi kórház tüdő és bélosztályán dolgozott, később az elmeosztályon medikus. 1922-ben a Semmeringi gyógyintézetben dolgozik, ahol mozgásterápiával is foglakozott.

A következő fontos állomás karrierjében 1928-1929-ig tartó időszak a Volkssanatorium Mauer volt. Ennek az intézetnek orvos-igazgatója, ahol különböző gyógymódok egyesítésével foglalkozott: torna, fizikoterápia, diéta, aktív életrend kialakítása a betegek számára, amelybe színházlátogatások és egyéb sport tevékenységek is beletartoztak. Tovább mélyítette tudását a fizikoterápia terén 1930-38 között, amikor a bécsi Fizikoterápiai Intézet munkatársa volt. Ebben az időszakban, mint orvosszakíró tevékenykedett és publikált neves orvosi lapokban.

1938-ban hazatért Magyarországra. 1945-től egészen haláláig a Gyógypedagógiai Tanárképző Főiskola tanszékvezető tanára volt. Ez biztosította a keretet a módszerei megalapozásához. A gyakorlati munkát egy kis pincehelyiségben kezdte meg a Klotild u. 4. alatt. Ebből a kisszobából nőtte ki magát a nemcsak Magyarországon, hanem külföldön is ismertté vált intézet. Munkájának gyümölcsét sajnos nem élhette meg, ahogy az első huszonhárom végzett konduktor átvette diplomáját, születésnapján szeptember 11.-én érte utol a halál.

\section{Pető András nevelésfilozófiája}

Kozma $(1994,27$.$) a következőket írta Pető nevelésfilozófiájáról: „Azt tartotta, hogy senkiről$ sem szabad lemondani, s ha fokról fokra csak valamivel is előrébbre jut valaki a mozgás a beszéd a munka megtanulásában, máris sokkal több lesz, mint volt, s igenis lehetséges újabb és újabb képességekkel felruházni azt a gyereket, felnőttet, akinek a központi idegrendszere sérült." Ez azért volt forradalmian új megközelítés, mert a második világháború előtt a relatív önellátásra képes Little-kóros gyerekeket Nyomorék Gyermekotthonban helyezték el. Gyógypedagógusok foglalkoztak velük és tanították be cipésznek vagy kertésznek. A központi idegrendszeri sérülés következtében gyógyíthatatlannak vélt legsúlyosabb állapotúakat pedig elfekvőkben helyezték el.

Nagyon fontosnak tartotta a precizitást, szorgalmat és aktivitást, ezt önmagától, munkatársaitól és neveltjeitől egyaránt megkövetelte. A pozitív pedagógia híve volt, mert hitt abban, hogy neveléssel az ember jobbá tehető, „a jót kell kihozni az emberekböl” (Háry,1997,15.)

\section{A konduktív pedagógia alapelvei}

A Pető professzor által kidolgozott konduktív módszer lényegét a következő szemléletes leírás által lehet legjobban megvilágítani: „A feladatok sorának, mint a zenemünek lejátszója, megvalósítója a zenekar (a mozgásterápiai kezelők és a gyerekek együttese, mely egyrészt együttmüködik, másrészt fontos, hogy ne botfülü zenészekből álljon. A zenészeknek egy bizonyos hallással kell rendelkezniük, hogy a kottát megfelelően tudják lejátszani” (Háry, 1997, 35.). Vagyis a gyerekek számára a konkrét teendőket versikék és mondókák kíséretében játékos formában kell átadni. Így lehet örömmé tenni a feladatvégzést. A sikeres tanulást különböző eszközök teremtik meg. Az összhang a „karmester” azaz konduktor által jön létre. A negatív értékeléseket és megnyilvánulásokat szigorúan kerülni kell. A bénult, gyengébb vagy 
ügyetlenebb jelzők használata tilos, a konduktív pedagógia nem tesz különbséget egészséges és sérült végtag között, mindkettőt felváltva kell használni.

A „kézgyakorlat” már egészen a kezdetektől fontos szerephez jutott. Pető körbe ültette a neveltjeit és mondókák segítségével ráhangolta öket a csoportos cselekvésre, így magukra, de csoporttársaikra is egyszerre kellett figyelniük. A kézgyakorlat máig legfontosabb eleme maradt a mozgásos feladatsoroknak. A finom ritmikus újmozgások mozgósítják az agykéreg nagy részét, amely növeli a tanulás hatékonyságát.

A légző gyakorlat különböző mozgásokkal kapcsolódott össze. Gyakran történt vokálisokra a kilégzés. Néha egy-egy eröltetett nevetéssel szakadt félbe a mozgásgyakorlat. Mély belégzést számolásos kilégzés követte, hogy nyúljon a kilégzés időtartalma. A testi munka a fékezés vagy intenzitás növelése. Pető doktor véleménye szerint befolyással bírt a vegetatív regulatorikus egyensúlyra.

A konduktív pedagógiában a beteg nem passzív, hanem nagyon is tevékeny résztvevő a gyógyulási folyamatban. Pető jól tudta, hogy ezeknek a gyerekeknek nagy szükségük van a sikerélményre, hogy ez motiválja őket a tovább fejlődésben, ezt úgy teremtette meg, számukra, hogy rendszeresen bemutatót szervezett. Itt mindig egy-egy csoport kapott lehetőséget, hogy megmutassa, mennyit fejlődött. Pető András a kezdetektől egy integrált program kialakítását tüzte ki célul, mert úgy vélte, hogy „nem elég, ha valaki csak tanít, és nem lehet csak tornáztatni” (Háry, 1997,50.). Hangsúlyozta, hogy nem irányíthat minden funkciót más-más ember. A munka csak akkor lehet eredményes, ha különböző szakterületek eredményeit együttesen alkalmazzák, aki pedig ezeket kézben tartja az nem más, mint a multidiszciplináris figyelemmel rendelkező konduktor.

Korát megelőzve jött rá, hogy a gyermekek értelmi fejlődése csak a mozgásfejlesztéssel együtt lehet igazán hatékony és a kettő szoros összefüggésben áll egymással, vagyis az értelmi fejlődésben tapasztalható elmaradás az nem betegségtünet, hanem az inger és mozgásszegény környezet következménye. „Gondot fordított arra is, hogy a gyerekek számára cselekvésük az ö életük valamely problémája megoldásának eszköze legyen" (Háry, 1997, 52.). Fontosnak tartotta, hogy a gyerekek ne csak az önálló mozgásvégzés örömével legyenek gazdagabbak a bemutatókon, hanem más kulturális élményekhez is jussanak, így folyamatosan szervezett számukra színházlátogatásokat és kirándulásokat is. Ezt a hagyományt máig őrzik, és minden évben a Villányi úton megrendezik, az un. Pető Juniálist.

\section{A fejlesztőprogram részletes leírása}

A folytatásban egy konkrét konduktív fejlesztőfoglalkozás ismertetésére kerül sor (1. táblázat). A csoport létszáma összesen 8 fö, a megfigyelés ideje alatt 4 fö 3-4 éves óvodás. Fejlesztési idő: 2 óra 30 perc (melyben a pihenőidők, tízórai is benne vannak)

A konduktívpedagógia komplexitása nemcsak magában a fejlesztőprogramban érhető tetten, hanem abban is, hogy egészen csecsemőkortól felnőttkorig nyújt rehabilitációs lehetőséget. Szem elött tartva a korosztályok életkori sajátosságait és a probléma specifikusságát is. Az alábbiakban ismertetésre kerül, hogy az intézetben milyen részlegek találhatók és, hogy ezen területek mely korosztály fejlesztéséért felelösek.

Pető mindennél, fontosabbnak tartotta a prevenciót és a minnél korábbi fejlesztést. Már a kezdetektől az Alkotás utcai intézetben voltak un. mamás csoportok, ahol azt tanították meg az édesanyák számára, hogyan foglalkozzon fogyatékos csecsemőjével. Gasell, Thomas valamint 
KÜLÖNLEGES BÁNÁSMÓD, I. ÉVF. 2015/4.

1. táblázat: egy konduktív pedagógiai foglalkozás ismertetése (forrás: a Szerzö)

\begin{tabular}{|c|c|c|}
\hline \multicolumn{2}{|r|}{ Tevékenység } & \multirow[b]{2}{*}{$\begin{array}{l}\text { A fejlesztés célja } \\
\text {-ráhangolódás } \\
\text { - ismeret bővítés } \\
\text {-légzésfejlesztés } \\
\text {-ritmusérzék } \\
\text { fejlesztése (mely } \\
\text { előfeltétele az írás } \\
\text { tanulásának) }\end{array}$} \\
\hline 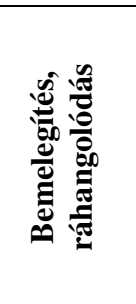 & $\begin{array}{l}\text { Érkezés után a fejlesztöterem játékpolcáról a gyerekek különféle } \\
\text { hangszereket (dob, síp stb.) választottak maguknak, majd hangszeres } \\
\text { kísérettel elénekelték a Dióbél bácsi dalt. } \\
\text { Majd a foglalkozást vezető konduktor megkérdezte tölük, hogy milyen őszi } \\
\text { gyümölcsöket ismernek. A gyerekek felsorolták a kedvenc gyümölcseiket, } \\
\text { majd, ismét énekeltek az Érik a szölö, és a Körtefát. Azért kíséri énekszó a } \\
\text { feladatokat, mert az éneklés fejleszti a légzést és a ritmusérzéket, ami } \\
\text { nélkülözhetetlen elöfeltétele az írástanulásnak. }\end{array}$ & \\
\hline 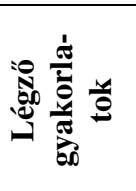 & $\begin{array}{l}\text { A szőnyegen a kezükkel hátuk mögé támaszkodva ültek, és légző } \\
\text { gyakorlatot végeztek, beszívásnál pipáló lábfejjel, kilégzéskor pedig } \\
\text { spiccelö lábfejjel. } \\
\text { Majd a Cini Cini Muzsika mondókára lábfejhajlításokat és bicikliző } \\
\text { mozdulatokat csináltak. }\end{array}$ & $\begin{array}{l}\text {-légző gyakorlatok } \\
\text {-lábfej gyakorlatok } \\
\text {-láberősítés } \\
\text {-elemi mozgások } \\
\text { fejlesztése }\end{array}$ \\
\hline 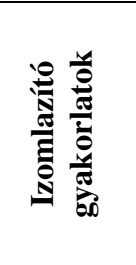 & $\begin{array}{l}\text { A következö feladatban a csoport színes karikákat húzott a combjára. } \\
\text { Elöször, meg kellett mondaniuk kinek milyen színü karika van a combján, } \\
\text { majd a karika segítségével nyújtva emelgették a lábukat felváltva a } \\
\text { levegőben a Gyere haza kicsi krokodil dalocskára. Majd, a Nyisd ki Rózsám } \\
\text { kapudat dalra terpeszt-zár gyakorlatot végeztek a karikák segítségével a } \\
\text { levegőben. Ez a feladat a spasztikus izumtunúsú gyermekek belső } \\
\text { combizmainak lazítására szolgál. }\end{array}$ & -combizomlazítás \\
\hline 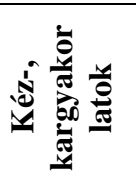 & $\begin{array}{l}\text { Ezt követően felhúzták a karikát egy kék plüss dinó, a Dinó Dani nyakára } \\
\text { két kézzel, illetve váltott kézzel. Ez a gyakorlat a felső végtagú } \\
\text { monoparézises gyerekeknek, nagyon fontos, hogy ne csak az egészséges } \\
\text { kezüket használják. }\end{array}$ & $\begin{array}{l}\text {-kéz-, } \\
\text { karerősítés, } \\
\text {-ujjak nyújtása, } \\
\text { feszítése }\end{array}$ \\
\hline 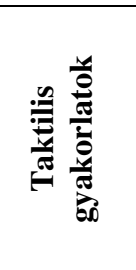 & $\begin{array}{l}\text { Terpeszülésben gurították egymásnak a labdát, majd az egyik talpuk alá } \\
\text { tették a kis labdát és görgették kifelé-befelé az Erre, kakas erre tyúk címú } \\
\text { mondókára. Ezután mindkét talpuk alá kaptak egy-egy labdát és úgy } \\
\text { görgették az Áspis kerekes dalra. Ez a feladat a taktilis ingerlést szolgálja, } \\
\text { illetve a lábfejizomzatának átmozgatását. A labdás gyakorlatsor lezárásaként } \\
\text { labdával a bokájuk között elugráltak a labdás kosárig és meg kellett } \\
\text { próbálniuk a bokájuk között lévő labdát bepottyantani a kosárba. }\end{array}$ & $\begin{array}{l}\text {-taktilis ingerlés } \\
\text {-lábfejátmozgatása }\end{array}$ \\
\hline 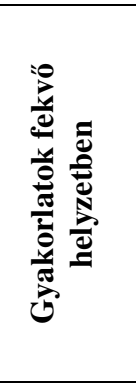 & $\begin{array}{l}\text { A fejlesztöprogram fekvő része azzal vette kezdetét, hogy hason fekve } \\
\text { pipáló lábfejjel feküdtek és kulcsolt kézzel harangoztak maguk elött a } \\
\text { Harangoznak délre és a János bácsi dalokra. A feladatsor következő eleme } \\
\text { az volt, hogy átkulcsolták a lábukat és maguk felé húzták felváltva, majd } \\
\text { mind a két lábat átkulcsolva, így hintáztak a Hinta-palinta címú énekre. } \\
\text { A dinó, számára a gyerekeknek a csípőjüket megemelve hidat kellett } \\
\text { csinálniuk, hogy át tudjon bújni a híd alatt, miközben a Búij, bújj zöldágat } \\
\text { énekelték közösen. A csípő lazítás azért nagyon fontos, mert ha a csipő és a } \\
\text { medence környéki izomzat feszes, az kihat az egész lábizomzatra. Például: } \\
\text { Nem tudja letenni rendesen a sarkát, így egyenlőtlenül oszlik el a teher. }\end{array}$ & $\begin{array}{l}\text {-csípő lazítás } \\
\text {-hasizom erősítés }\end{array}$ \\
\hline 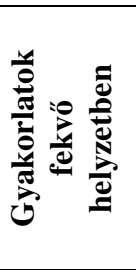 & $\begin{array}{l}\text { A hidas gyakorlatot egy kis hasizom erősítés követte nyújtott karokkal, és } \\
\text { lábakkal. Hason fekve gurultak a szőnyegen, utána hason fekvésben nyújtott } \\
\text { karokkal doboltak majd vállból emelték föl a karjukat a Dibi-dobi hátán } \\
\text { mondókára. Majd egymással szembe feküdtek hason a szőnyegen és így } \\
\text { gurították át a szemben lévőnek a labdát. Ezt követően már nem egyedül, } \\
\text { hanem párban kellett gurulniuk, úgy hogy a párok kezei kulcsolásban voltak } \\
\text { a lábaik, pedig nyújtva. Majd párban egymás segítségével álltak fel. }\end{array}$ & $\begin{array}{l}\text {-hasizom erősítés } \\
\text {-páros feladat } \\
\text { megoldás }\end{array}$ \\
\hline
\end{tabular}

Folytatás a következö oldalon... 
KÜLÖNLEGES BÁNÁSMÓD, I. ÉVF. 2015/4.

1. táblázat folytatása:

\begin{tabular}{|c|c|c|}
\hline \multicolumn{2}{|r|}{ Tevékenység } & A fejlesztés célja \\
\hline 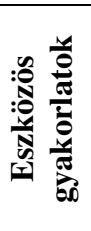 & $\begin{array}{l}\text { A konduktor a szőnyegszélén álló csapatnak adott egy-egy nagy hullahopp } \\
\text { karikát, amit váltott kézzel kellett elgurítaniuk a terem másik végébe. A } \\
\text { folytatásban a szőnyegre lehelyezett hullahopp karikának az ívén kellett } \\
\text { körbe lépkedniük, majd ezt megismételniük sarkon járva. Zenére ki-be } \\
\text { ugráltak a gyerekek a karikából és közben nagyokat kacagtak, láthatóan } \\
\text { nagyon élvezték a feladatot. Ez után békaugrással ugráltak. }\end{array}$ & $\begin{array}{l}\text {-eszközhasználat, } \\
\text {-manipuláció } \\
\text { fejlesztés }\end{array}$ \\
\hline 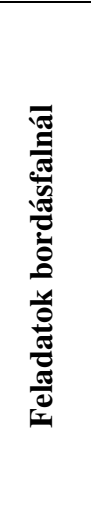 & $\begin{array}{l}\text { A gyerekek kis balett táncosokká változtak, és gördültek lábujjhegyre, és } \\
\text { sarokra, végül talpra miközben a Hopp Juliskát dúdolták. A lábukat aztán } \\
\text { föltették a bordásfal legelső fokára, és így rugóztak váltott lábbal. Ezt } \\
\text { követően kishegymászókká változtak és váltott kézzel-lábbal } \\
\text { fölkapaszkodtak egészen a bordásfal csúcsáig. A folytatásban a gyerekeknek } \\
\text { a bordásfalba kapaszkodva jobb és bal lábbal, majd pedig páros lábbal fel } \\
\text { kellett lépniük a bordásfal elé helyezett labdára. Leültek a labdára és már } \\
\text { kapaszkodás nélkül a labdán egyensúlyozva nyújtották előre a bal, jobb, } \\
\text { majd pedig párban a lábukat. Tovább nehezedett a gyakorlat, mert a kis } \\
\text { társaság kapott egy-egy babzsákot, amit a lábujjaikkal fogva meg kellett } \\
\text { emelniük. Ez után a csoport a labdán ülve át kellett, hogy hajítsa a babzsákot } \\
\text { a karikán, amit a konduktor tartott eléjük. Majd a bokájuk között lévő } \\
\text { labdával lépegettek. A labdás feladatsor azzal végződött, hogy állva két } \\
\text { kézzel maguk elé dobták a labdát és kapták el. }\end{array}$ & $\begin{array}{l}\text {-egyensúly, } \\
\text { koordinációs } \\
\text { készség fejlesztés } \\
\text {-eszközhasználati } \\
\text { készség fejlesztése }\end{array}$ \\
\hline 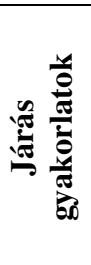 & $\begin{array}{l}\text { Járógyakorlatok, amelyhez a konduktor egy akadálypályát készített. } \\
\text { Libikókán fölsétálva kellett eljutniuk a szőnyegig, ahol bukfencezve jutottak } \\
\text { át a hídon, ami két rúdból állt. A hídon csak egyféleképpen lehetett átjutni, } \\
\text { ha a lábukat egymás elé helyezve lépkedtek. Az akadálypálya következő } \\
\text { része lefektetett karikákból állt. A veszélyes mocsáron csak úgy lehetet } \\
\text { átkelni, hogy felváltva nehezedtek a lábukkal, hol az egyik, hol a másik } \\
\text { karikába. Végül zsámolyról zsámolyra lépegetve. }\end{array}$ & $\begin{array}{l}\text {-járás gyakorlatok } \\
\text { nehezített } \\
\text { körülmények között }\end{array}$ \\
\hline
\end{tabular}

Phelps ismereteit felhasználva történtek a fejlesztések azzal a különbséggel, hogy a háton végzett gyakorlat után egy hason végzett gyakorlat következett, majd újból háton, végül pedig egy ülve végzett. Ezek az un. elemi mozgások, amiket normális esetben minden csecsemő a fejlődése során automatikusan elsajátít, de kimaradnak a központi idegrendszer sérülése következtében. Ezért szükséges megtanítani a sérült babáknak, mert ezen a mozgásfázisok egymásra épülnek, és adják a megfelelö alapot a járáshoz.

További fejlesztés volt, hogy az ujjak nyújtása és hajlítása is szerepelt, sőt a többi ujj egyenként való összeérintése is. Kombinált hajlítások és nyújtások is megtalálhatók voltak a gyakorlatsorban úgy, mint csipő nyújtás térdhajlítással. Pálca egyik kézből a másik kézbe történő átvétele. Phelps feldatai annyival lettek továbbfejlesztve, hogy kiegészültek finom kézmozgásokkal és sok helyzetváltoztatással. A kúszási gyakorlatok során Fay előismereteire támaszkodtak azzal a különbséggel, hogy, nem passzív, hanem aktív játékos formában alkalmazták ezeket. A kúszás a felállást, majd pedig a járástanulást készíti elő. A kúszás segít abban, hogy az idegpályák között megfelelő mennyiségü kapcsolat alakuljon ki. Ezek az idegi kapcsolatok teszik lehetővé, hogy az agy különböző részei hatékonyan tudjanak kommunikálni 
egymással. A foglalkozás a napi tornagyakorlatok betanításán túl elősegítette a baba-mama interkommunikációt az arckifejezés és beszédhangutánzó gyakorlatok által. Továbbá a babaápolásában is segítséget nyújtottak az édesanyáknak a helyes étkezés és megfelelö bilihasználat kialakításával.

\section{A konduktív pedagógia célcsoportjai}

Napjainkban mindez a Korai Fejlesztö Központ feladatköre, azon belül is a mamás bentlakó csoporthoz tartozik. A Korai Fejlesztő Központ egész napos foglalkozást, és hetes bentlakást biztosít a vidéki sérült gyermekek és szüleik számára. 18 hónapos kortól 6 éves korig egy hónapos intervallumokban fogadja a sérülteket. A fejlesztés csoportosan a szülők közremüködésével történik. Ez alapozza meg a bentlakó óvodába való beilleszkedést is. A Korai Fejlesztő Központ másik fontos feladatköre a prevenció a konduktív szürés un. első vizsgálat által. Az első vizsgálat célja a megelőzés, és a másodlagos károsodások kialakulásának megelőzése, csökkentése. A szülő szemléletének formálása, hogy megértse és elfogadja a konduktív pedagógia alapelveit.

A következő célcsoportba az óvodások tartoznak. Itt fontos szempont volt, hogy az óvodai foglalkozások szerves egységet alkossanak a gyerekek napirendjével, továbbá, hogy olyan játékokon keresztül történjen a fejlesztés, amit egy hagyományos óvodai foglalkozás is tartalmazott. Pető azt hangsúlyozta, hogy „ne a tananyag legyen speciális, hanem az oktatási és nevelési módszer a tananyag a normál tananyag legyen" (Háry, 1997, 119. o.).

Az iskolás-életkorú gyerekek integrációját is elősegítették, hogy később képesek legyenek beilleszkedni a normál iskolai keretek közé. Akkoriban, de még ma is vannak, akik azt a nézetet vallják, hogy ezeknél a gyereknél nem alakítható ki a beszéd és írás olyan mértékben, hogy az megfeleljen a normának. Pálcafogással végezték a gyakorlatokat ezzel különböző koordinációs feladatokat végeztek a levegőbe. Majd ujjaikkal célzási feladatokat csináltak, és a lapok különböző részeire céloztak. A pálcás gyakorlatok elősegítették a kéz és az ujjak finom motorikus fejlesztését, és a kéz izmainak ellazítását. A térben való célzott irányokba való mutogatás a téri orientációt hívatott fejleszteni, ami elősegítette a füzetben való tájékozódást. A számukra készült füzetek nagyobb sortávolságúak voltak. Például egy athetotikus gyermek írásképepe nagyon szaggatott, túl erős vagy túl gyenge ceruzavezetés jellemzi. Az ilyen problémájú gyermek számára kezdetben rögzíteni kell a füzetet, és fokozatosan kell a lapok sortávolságát csökkenteni.

A legtöbb neveltnek az első osztály tananyagának megtanulása több időt vett igénybe, viszont később már jó alapokkal és könnyebben vették a többi osztályt. Amennyiben sikerült ezeknek a gyerekeknek integrálódniuk a normál iskolába továbbra is figyelemmel kísérik megfelelő testi és lelki fejlődésüket. Ez a Konduktív Gondozó Központ egyik legjelentősebb feladata. Folyamatosan kapcsolatban állnak a fogyatékos gyermeket befogadó közoktatási intézménnyel iskola és óvodalátogatások révén. Továbbá, olyan szakszolgálatokkal vannak kapcsolatban a Konduktív Gondozó Központ munkatársai, mint az Országos Tanulási Képességet Vizsgáló Szakértő Rehabilitációs Bizottság, Pályaválasztási és Nevelési Tanácsadó.

Az utolsó korcsoport a felnőttek. A rehabilitáció főleg a motorikus diszfunkciós felnőttek esetében járt és jár sikerrel. 18. életévtől kezdve kerülnek át a neveltek a felnőtt rehabilitációs csoportba. Itt a fejlesztés az elvesztett képességek, visszaszerzésére fókuszál, hogy ez által az 
egyén vissza tudjon illeszkedni a munka világába. A program bejárórendszerben müködik. A csoportokat hasonló diszfunkciósok alkotják. Hetente két-három alkalommal történik a fejlesztés két órás komplex program keretein belül.

\section{Pető módszer alkalmazása külföldön: Move and Walk Svédország}

A Pető Módszert több országban átvették és beépült a gyógypedagógiai gyakorlatba. Külföldön az integrációs kezdeményezések már több mint 25 éve vette kezdetét. A mozgalomban világszerte kitüntetett szerep jutott a fogyatékos gyermeket nevelö szülöknek, hiszen gyermekeik elkülönültek a társadalomtól és ez egy fajta megbélyegzettséget jelentett.

Falus $(2001,440$.) a következőket fogalmazta meg: „Az 1960-as évek végén a skandináv országokban jelentek meg és terjedtek el az első integrációs törekvések. Majd, 1975-ben az USÁ-ban fogadták el azt a modellértékü törvényt, amely elöírta a speciális tanulási problémával küzdő gyermekek felkutatását és számukra egyéni fejlesztési terv kidolgozását, amely megjelöli nekik, a legoptimálisabbnak vélt oktatási formát".

A sok ország közül, ahol a konduktív pedagógia gyökeret vert különösen jelentős a svédországi Move and Walk mozgalom Gothenburg-ban. A Move and Walk 1997-ben Nässjöben jött létre. Jelenleg Gothenburg-ban, Stockholm-ban és Malmö-ben vannak kirendeltségeik. Rehabilitációs és képzési tevékenységet is végeznek országszerte. A müködésükhöz szükséges anyagiakat az országos tanács és a helyi szervezetek biztosítják. A müködés hatékonyságát évről-évre ellenőrzi a Svéd Nemzeti Egészségügyi Tanács, valamint a Svéd Oktatásügyi Hivatal. A legelső Move and Walk még 1991-ben jött létre Budapesten. A svédországi tevékenységek Tóthné Horváth Eszter irányításával kezdődtek meg. A szülök kezdeményezték egy intézmény megalapítását Nässjö-ben, majd nem sokkal később 1999-ben Stockholm-ban létrejött a következő. 2005-ben alapították a gothenburgit. 2008-ban tovább bővült az intézményi hálózat egy konduktív neveléssel foglakozó speciális iskolával. A Move and Walk Intenzív négyhetes egyéni és kis csoportos tréninget nyújt gyermekeknek és felnőtteknek egyaránt (Net 1.).

\section{Helyzetfeltáró beszélgetések hazánkban és svédországban}

A következőkben két interjú segítségével térünk ki a hazai és a svédországi konduktív pedagógia gyakorlati megvalósulására.

Az 1. mellékletben volt konduktorommal készített interjú összefoglalója olvasható. A beszélgetés első része magára a konduktorra koncentrált. A konduktív pedagógia alapfogalmait is definiálta, illetve részletesen kifejtette, mint például intervallumnevelés vagy első vizsgálat. Részletesen felvázolta az első vizsgálat menetét és jelentőségét. Az első vizsgálat azért kiemelt fontosságú, mert ez a konduktív nevelés legelső lépcsőfoka, csak az kerülhet a Pető Intézet gondozásába, aki túlesett ezen a vizsgálaton. Itt történik ugyanis a gyermek állapotának felmérése és az életkorának megfelelő csoportba való besorolása, a további fejlesztés meghatározása. Ezt követően megbeszélésre került az is, hogy milyen különbségek és hasonlóságok voltak a csoportok között. A csoportok kapcsán feltárásara kerültek az életkor specifikus konduktív komplexprogram egységei, és ezen egységek fejlesztési területei, majd az iskolalátogatások hatásainak feltérképezésére került sor. Szó volt, az integrációról, és az olyan programokról, amelyek elősegíthetik a fogyatékos beillesz-kedését a társadalomba. A riport lezárásaként néhány sikertörténet is bemutatásra kerül. 
KÜLÖNLEGES BÁNÁSMÓD, I. ÉVF. 2015/4.

A 2. számú mellékletben egy svédországi konduktorral készített skype interjú bemutatása történik. Az interjú koncentrál az ő személyes élettörténetére, továbbá arra, hogy mik a hasonlóságok és különbségek a magyarországi és a svédországi Pető Módszer között, egyáltalán vannak-e vagy egy az egyben a magyar mintát követi az ottani gyakorlat.

A két ország közötti különbség az, hogy a szülőknek és gyerekeknek nagyobb beleszólásuk van, hogy hogyan is történjen maga a fejlesztés. A konduktori munkába sokkal aktívabban vesznek részt a szülők, illetve a gyerekek mellé kirendelt személyi asszisztensek, mert Svédországban minden fogyatékosnak alanyi jogon jár egy ilyen személy, aki segíti öt a napi önellátási tevékenységekben. A hazai gyakorlatban az utógondozásos forma a legelterjedtebb, míg ott inkább az intervallumnevelést preferálják. A konduktív komplexprogram felépítése csak annyiban tér el, hogy ott nagyobb hangsúlyt kap a fekvő rész.

A munkakörülményekben lényeges különbség, hogy törekszenek a konduktornak minden lehetséges eszközt megadni, hogy a lehetö legjobbat hozza ki magából és a neveltjéből is. Továbbá, fontosnak tartják, hogy jó legyen a kollegák egymással való kapcsolata, így sok csapatépítő programot szerveznek számukra. Az intézmény nem állami finanszírozású, hanem privát üzemeltetésü. Hasonlóságok például, hogy ott is nagy hangsúlyt fektetnek a helyes tisztálkodási és étkezési szokások kialakítására, illetve az iskolás életkorú gyerekek kognitív és grafomotoros fejlesztésére.

\section{Összefoglalás}

A tanulmányban röviden ismertetésre került Pető András életútja, illetve a konduktív pedagógia alapelvei és gyakorlati megvalósulása. Az elméleti háttért résztvevői megfigyeléssel és interjúkkal egészítettük ki. Az első interjúból, a hazai gyakorlatba nyerhet bepillantást az érdeklődő; míg a második beszélgetés során a külföldön alkalmazott napi gyakorlatból kaptunk teljesebb képet. A Pető Módszer egy kulcsot ad a mozgássérült emberek kezébe, és megtanítja, hogyan élhetnek a fogyatékosságuk ellenére normális életet.

Hazánkban 1997 óta kevés konduktív pedagógiai mü születik. Ezzel ellentétben külföldön igen élénk érdeklődés mutatkozik a módszer iránt, ennek egyik ékes bizonyítéka Svédország. Ennek a hazai hiányosságnak a pótlása még várat magára.

\section{Irodalom}

Falus, I. (2001.) A különleges bánásmódot igénylő gyermek. In I. Falus (Ed.), Didaktika Elméleti alapok a tanítás tanulásához. Nemzeti Tankönyv Kiadó, Budapest. 435.-464

Háry, M. ( 1997.) A konduktív pedagógia története. Mozgássérültek Pető András Nevelő-képző és Nevelő Intézete, Budapest.

Kozma, Gy.né (1994.) Pető Andreás (1893-1993). Mozgássérültek Pető András Nevelőképző és Nevelö Intézete, Budapest.

Net 1: Letöltés: 2015.12.10. Web: http://www.movewalk.se/Engelska/AboutMoveWalk/ Ourhistory.aspx 
KÜLÖNLEGES BÁNÁSMÓD, I. ÉVF. 2015/4.

\section{Mellékletek}

Interjúalany: B. Cs.

Készítette: Oravecz Adrienn

Helyszín: Pető Intézet

Interjú időpontja: 2013.10.24.

- Mióta dolgozik konduktorként?

- Konduktorként 1982 óta, de a Pető Intézetbe 1987. augusztus 18.-án léptem be. Ennek volt egy folyamata először konduktorjelöltek voltunk, gyakornokok, majd az államvizsga után konduktorok.

- Miért választotta a konduktori hivatást?

- Első sorban az motivált, hogy szerettem volna segíteni azoknak az embereknek, akik valamilyen hiányossággal küzdenek, így választottam a mozgássérülteket. Úgy gondoltam, hogy amit megtanulok, vagy megtanulhatok, azt úgy fogom tudni átadni a számukra, hogy az életminőségüket nagymértékben javítani fogja.

- Miért pont éppen ez a speciális csoport? A mozgássérültek. Lehetett, volna akár vakok vagy autisták.

- Ök igénylik a legnagyobb szaktudást és gondoskodást.

- Esetleg valami családi érintettség?

- Személyesen is ismertem már a jelentkezésem előtt is mozgássérült fiatalt, akinek pozitív és magával ragadó személyisége volt, épp ezért nagyon elkeserített, hogy tolókocsiban éli le az életét. Ekkor olvastam és hallottam, először a Pető Intézetről, hogy itt milyen segítséget tudnak nyújtani a mozgássérülteknek, hogy mi az a Pető Módszer, ami a világon egyedülálló, ami módszerként és nem terápiaként képes hatni az egész személyiségre. Ez a fiatal motivált arra, hogy jelentkezem a konduktornak, mert mindenképpen szerettem volna segíteni neki és sorstársainak.

- Mi motiválja nap, mint nap?

- A sikerek. A siker, amit mindennap megkapok a gyerekektöl. A szeretet, amit mindennap tudok adni és kapni a gyerekeimtől. Mindaz, amit elértek már ez alatt az eltelt 35 év alatt és visszajelzésként hozzám elérkezik, hogy milyen szerencsés és sikeres életutakról van tudomásom.

- Az Ön szakterülete a Korai Fejlesztö és a Kunduktiv Gondozó Központ. Mesélne a müködésükről? Milyen feladatokat látnak el? Hogyan segítik ezek a központok a mozgássérülttek integrációját?

- A területünkre, elsősorban integráltan élö gyerekek érkeznek. Lehetséges az első vizsgálat után a területünkre kerülni csoportos vagy egyéni foglalkozásra. A csoportos foglalkozás is több területet érinthet. Vannak olyan súlyos mozgásállapotú gyerekek, akik csak szülővel együtt foglalkoztathatók. Ök elsősorban intervallumnevelésben vesznek részt. Vannak olyan alacsony életkorú gyermekek, akik un. korai fejlesztésben részesülnek, ahol szüleiknek segítünk meg tanulni, hogy melyek azok a gyakorlatok, napirendek, napi rutinok, amiket az otthonukban alkalmazniuk kell, annak érdekében, hogy fejlődést arra a szintre tudjuk felhozni, amire az egyén képes. Vannak egyéni foglalkozások is, amelyek szintén intervallumnevelésre épülnek. Az intézet egyéb területeiröl elbocsátott gyerekeknek további csoportos foglalkozást biztosítunk mozgásállapotuk megőrzése érdekében.

- Mit jelent az intervallumnevelés? 
- Meghatározott időtartalmú foglalkoztatás, tehát behatárolt idejü. Ez 3-4 hét illetve egy egész tanévet is felölelhet. Esetleg szakaszos visszatérésre is van lehetösége a gyermeknek amennyiben a mozgásában állapotváltozás áll be.

- És heti hányszor vannak ezek a foglalkozások?

- Ezt mindig az egyén mozgásállapota és fejlődési szintje határozza meg.

- Mit jelent az elsö vizsgálat? Mert én tudom, de egy átlagember számára ez ismeretlen fogalom. Elmondaná miböl áll ez, és hogy mi a jelentösége?

- Az első vizsgálatra olyan gyermekek érkeznek, akik kapcsolatba szeretnének kerülni a Pető Intézettel, illetve a Pető Módszerrel, mert ezt tartják egy olyan fejlesztési formának, amely által a legtöbbet nyújthatják a gyermekük számára. A vizsgálatra szakértői, szakorvosi javaslat vagy szülöi igény alapján lehet időpont egyeztetés után lehet jelentkezni. Ez a kicsik számára szerdai napon, míg a nagyobb életkorúak 3 vagy annál idösebbek esetében hétföi napon történik. A szülő kikérdezésével un. anamnézist készítek, ez a terhesség kezdetétől a születés pillanatáig illetve az azt követő időszakot öleli fel. Milyen orvosi vagy szakorvosi ellátásban részesültek vagy milyen fejlesztést kaptak ez idáig. Ennek alapján történik az operatív megfigyelés a vizsgálat során. Ez természetesen kiterjed a mozgás és a kognitív képességekre egyaránt. Az összegzésben véleményt adok, arról hogy az Intézet melyik területre tudom őt beosztani és milyen foglalkozásban tudjuk öt részesíteni.

- Ezen a vizsgálaton különféle végrehajtandó feladatokat kapnak?

- Igen természetesen. Mert csak így lehet megfelelöen megfigyelni és felmérni a gyermek mozgásszintjét és értelmi fejlettséget.

- IQ tesztet is csinálnak a vizsgálat során?

- Nem azt nem, de természetesen a beszélgetés és a gyermekröl kapott általános ismeretek segítségével sok évnyi tapasztalatom által meg tudom állapítani, hogy az életkori átlagnak megfelelő-e a vizsgált gyermek intelligenciája.

- Hány éves kortól lehet elvégezni az elsö vizsgálatot?

- Azt valljuk, hogy már a nulla éves kortól, azaz a megszületés pillanatától, ha az anamnizísében olyan terhelö adatok szerepelnek, amely feltételezi, hogy olyan központi idegrendszeri sérülés alakult vagy alakulhatott ki szürést végzünk. A későbbiekben megkezdődik a komplex konduktív fejlesztés. Ilyenkor a szülő-gyermek kapcsolatának erősítése történik. Például segítünk kialakítani a táplálás módját, a testi kontaktust az anya és gyermeke között. Ebben a korai életkorban nagyon hangsúlyos a taktilis ingerek kialakítása és ezek közvetítése a gyermek felé, illetve a különféle nyújtógyakorlatok. A tapasztalatom az, hogy első vizsgálatra jelentkezés zömében akkor történik meg, amikor beindulnak, az un. klasszikus mozgásformák, és szembesül a szülő azzal a ténnyel, hogy az ő gyermeke még nem tart az életkornak megfelelő mozgásszinten. Gondolok itt a fejemelésekre, fordulásokra.

- 6 hónapos kortól?

- Elsősorban 2-4 hónapos kor között.

- A vizsgálaton a szülö is részt vesz vagy csak Ön és adott gyermek?

- A gyermek és szülő együtt.

- 2013. 09.20.-án megfigyeltem egy konduktív foglalkozást. Mesélne a csoportról, és hogy milyen problémával küzdenek azok a gyerekek?

- Igen, ez egy tavaly indult kicsi csoport 3 és 4 éves életkorban vannak. Van közöttük izomtonuseloszlási zavaros. Ami azt jelenti, hogy a felső végtagban lehet egy csökkent izommüködés, míg az alsóban spasztikus, vagy éppen fordítva. Van köztük olyan gyermek, akinek féloldali sérülése van, tehát az adott oldali kéz és láb feszessége a probléma. Van köztük 
KÜLÖNLEGES BÁNÁSMÓD, I. ÉVF. 2015/4.

olyan is, akinek un. monoparézise azaz egy adott végtagi sérülése van. Mozgáskoordinációs nehézségekkel küzdö.

- Autista volt köztük?

- Nem abban a csoportban nem volt.

- Ma is megfigyeltem egy csoportot. Milyen hasonlóságok és különbségek vannak a két csoport között? Az életkor az nyilvánvalóan különbség.

- Hasonlóság közöttük, hogy mind a két csoportban un. központi idegrendszeri sérültek vannak. Ebben csoportban találkozhatunk magatartási és intellektus problémával küzdő gyermekkel is. Van olyan gyermek, aki intellektus szempontjából már a tanulásban akadályozott. Az eltérés a programban is megmutatkozik, hiszen a konduktív komplexprogram mindig életkor specifikusan épül föl. Az alacsonyabb életkorúaknál játékosabb formában történik a fejlesztés, míg ebben a csoportban már az iskolás életkornak megfelelően. Egy határozottabb programvezetéssel és a feladatok számának növelésével. Ritmikus íntendálásnak nevezzük az egytől- ötig való számolást, amire a gyermekek a mozgást kivitelezik, illetve magát a nyújtást vagy a lazítást elérjük.

- Van valami jelentösége, hogy egytöl-ötig kell számolni és nem tovább?

- Petőnek ez volt az alapötlete, mert azt figyelte meg, hogy ez alatt az időtartam alatt lehet elérni a nyújtást. Amivel ezt lehet még fokozni az a feladatmondás hosszúsága. Lehet egy feladatot, egy gyakorlatot elhadarni és lassan számolni ötig, vagy úgy is lehet, lassan mondom, és lassan számolok rá, ezt persze nagymértékben meghatározza, hogy milyen súlyosságú és diagnózisú az adott csoport. Visszatérve a csoportokra. Nem utolsó sorban a két csoport között az is különbség, hogy egy délutáni csoportba sokkal több gyakorlatot lehet beépíteni rövidebb idő alatt, mert ők már túl vannak egy felkészítő szakaszon. A kicsik még csak a felkészítő szakaszban tartanak.

- Automatikusan kerülnek át az életkornak megfelelö csoportba vagy újabb felülvizsgálaton kell részt venniük, hogy átkerüljenek egy a koruknak megfelelö csoportba?

- Nem ez általában automatikusan történik. Én azt gondolom, és azt vallom, hogy ennek, soha nem lehet vége senki számára ennek a fejlesztésnek és mozgásfoglalkozásnak, mert a növekedéssel együtt az izmok és az ízületek változása növekedése során, ha nem képesek egymást követni ezek a sorozatos növekedések, akkor létrejönnek a kontraktúrák, amik az idősebb életkorban komoly problémákat okozhat. Ezért a kontrakúrák megelőzése és a mozgásállapot megfelelö színtentartása továbbra is cél marad.

- Milyen egységekböl épül föl a konduktív foglakozás és az egyes részek mely területeket fejlesztik leginkább?

- Ez két kérdés egyben. A konduktív komplex programnak van, egy un. klasszikus felépítése. Az első megoldási és helyzetváltoztatási mód a fekvő helyzet. A fekvő helyzetben végzett tornagyakorlatok után következnek a manipulációt fejlesztő feladatok. Ezt követi az álló helyzet, ami lehet egy nyújtás a bordásfalnál megoldva, majd ezt követi egy járógyakorlat. Miután már elértük mindazt a nyújtást és koordinációfejlesztést, azt az optimális állapotot, akkor jöhet maga a helyzetváltoztatás megoldási módjainak, a nehezített járásformák elsajátítása. A manipulációs feladatsort ülve végezzük. Természetesen minden feladatsor tartalmaz, un. nagy bázismozgásokat. Idetartoznak a lábemelések, láb oldalra vitelek és talpra tételek. Illetve a bordásfalnál való nehezedés, és fokaira való feltétel is ide sorolandó, de már koordinációfejlesztés is történik. Az ülöfeladatoknál a karok oldalra lendítése, itt hangsúlyos szerepet kap a szem és kéz koordináció összehangolása, ezáltal pedig fejlődik a téri orientáció. Minden egyes feladattal maga az intellektus is fejlődik, hiszen ez a beszédmegértés alapja, 
hogy tudja, a saját testével a feladaton keresztül mit lehet elérni és meddig lehet ezt nyújtani, alkalmazni, hogy az számára optimális legyen, de a komfortérzete is megmaradjon. A járásgyakorlatoknál nagyon fontos, hogy közelítsen a normál testnevelés irányába. Én ezt végtelenül szorgalmazom, hiszen integráltan élö gyerekekröl van szó. Minden gyermek részt vesz az óvodai- iskolai testnevelésórákon. Nagyon jó, ha a maguk szintjén, a maguk módján meg tudják oldani azokat a feladatokat, amelyek részei a tantervnek. Teljes felmentéssel rendelkező gyermekünk jelenleg nincs, de vannak részleges felmentéssel rendelkezők. Ami azt jelenti, hogy az órán részt kell venniük, de nem kapnak osztályzatot az órai teljesítményükre.

- A manipulációs feladatsor kapcsán említette, hogy milyen szoros kapcsolat van az intellektus fejlettsége és beszéd megértésének képessége között. A konduktív pedagógia hármas egységben igyekszik fejleszteni az egyént, hiszen a motoros funkciók javulása pozitívan befolyásolja a beszédfejlödést és megértést, illetve a kognitív képességet is. Mit gondol, ez elösegíti, vagy hatékonyabbá teheti az anyanyelv és idegen nyelv elsajátítását?

- Úgy gondolom, igen. A gyerekek kitartóbbá válnak, mert a motoros és kognitívfunkciók fejlesztése ebbe a hármas egységbe ágyazva történik az intézeti foglalkozásokon. Az anyanyelv elsajátítása is erre a hármas egységre épül az óvodai és iskolai foglalkozásokon. A jó anyanyelvi alapok megkönnyíthetik az idegen nyelv tanulását. Az Intézetben nagy hangsúlyt kap a zene a ritmus. A fejlett ritmusérzék még inkább előnyösen hat egy idegen nyelv megtanulásakor, hiszen minden nyelv sajátos egyedi dallammal rendelkezik. Természetesen ez csak azokra a gyerekekre igaz, akiknél a kognitív képességek lehetővé teszik a helyes beszéd kialakulását.

- Véleménye szerint mitöl függ, hogy egy fogyatékkal élö ember mennyire tud integrálódni a társadalomba?

- Ez egy végtelenül bonyolult kérdés. Természetesen függ a szociokulturális háttértől, tehát a családi környezettől, amiben él. Függ attól a társadalmi környezettől, ahol jelenleg részt vesz az életében az óvodától, iskolától, hogy abban a közösségben milyen szerepet tölt be, mennyire befogadóak és elfogadóak vele. Mennyire tolerálják az ő másságát. A mai Köznevelési Törvény értelmében, ezt csak azok az intézmények tehetik meg, akiknek az alapító okiratában szerepel az annak a bizonyosfajta fogyatékosságnak az elfogadása, akiket ők befogadni és integrálni szeretnének. Van-e eszközparkjuk, amivel meg tudják oldani a fejlesztést. Sok gyermek, akinek az intézmény maga nem tudja biztosítani a fejlesztést, azok a Pető Intézetben kapnak, un. szakszolgálati ellátást. Van utazó konduktori szolgáltatásunk is, ezt leginkább vidéki intézmények veszik igénybe.

- Tudom, hogy az is feladata egy konduktornak, hogy óvodát és iskolát látogasson. Mi ennek a látogatásnak a célja és jelentösége?

- Ez közvetlen kapcsolat kialakítására ad lehetőséget az adott közoktatási intézménnyel, ahova az általunk gondozott gyermek jár. Ez általában úgy zajlik, hogy egy megbeszélt időpontban találkozunk az intézményvezetővel, illetve a gyermeket oktató pedagógusokkal, vagy akár az egész nevelötestülettel is. Rövid tájékoztatást adunk az adott gyermek problémájáról, konkrét diagnózisáról. Az általános tapasztalatom az, hogy nem igazán ismerik a gyermek tényleges, valódi problémáját, de ennek ellenére szívesen befogadják őket. Beszélünk arról, hogy melyek azok a praktikus tevékenységek, amelyeket a mindennapok során ök alkalmazni tudnak, mire kell figyelniük. Például egy féloldali sérült estében, arra, hogy az érintett oldalát megfelelően használja. Ha szabadtevékenység van, és az udvaron szaladgál, az érintett oldali végtagjait megfelelő magasra emelje, vagy mászókázás közben alternáló mozgással menjen föl, tehát váltott kézzel-, lábbal. Ez persze sokkal több odafigyelést igényel 
az intézet részéről. Az intézményekben egyre több a fejlesztőpedagógus is. Pozitívak a tapasztalataim, mert az intézmények szívesen fogadják a tőlünk kapott tájékoztatást és segédkeznek a fejlesztésben.

- Mit gondol az olyan kezdeményezésekröl, amikor egészséges emberek kipróbálhatják milyen vaknak, mozgássérültnek vagy egyéb fogyatékkal élönek lenni? Ön szerint segítik az ilyen programok az integrációt?

- Igen. Én nagyon bízom benne, hogy elindult annak a generációnak a felnevekedése, aki sokkal toleránsabb lesz. Erre két nagyon jó példát is tudok mondani. Mind a kettő a TÁMOP keretén belül, a sajátos nevelésigényü gyermekek kapcsán un. Érzékenyítő Tréninget tartottam. Az első már megtörtént az óvodában, és iskolákban a második pedig most történik a középiskolás életkorúak körében.

- Ez mit jelent pontosan?

- A tréning abból áll, hogy játékos feladatokkal megmutatjuk azokat a hiányosságokat, amivel egy fogyatékos, illetve itt kimondottan egy mozgássérült élhet. Például, vízzel teli pohárral kellett padon egyensúlyozniuk, amivel azt próbáltuk szemléltetni, hogy milyen bizonytalanul érezheti magát az a fogyatékos, akinek a kezével probléma van, tehát, ha nem tudja a megfelelö fiziológiás együtt mozgást müködtetni, mint egy egészséges. Korlátoztuk az aktív mozgásukat is, például kipróbálhatták és megtapasztalhatták milyen térdsínnel, járókerettel, vagy bottal járni. Továbbá, kipróbálták milyen fél kézzel teríteni, amit egy monoparizisben szenvedö naponta átél. Még a kicsik részéröl is döbbenetet tapasztaltam, de nagyon pozitív visszajelzéseket kaptam a tréning végén a résztvevőktől. Bízom benne, hogy ez az élmény mély nyomot hagyott bennük, és egy sokkal toleránsabb generáció növekszik fel ez által.

- Ez mennyi időt vett igénybe, vagy ezt most rendszeresen megszervezik majd?

- A kicsiknek ez egy kétszer 4 órás elfoglaltság volt délelőtt, nekik ez nagyon kimerítő is volt. A középiskolások számára folyamatos, az önkéntes szolgálaton belül lehet ezt választani, és heti egy alkalom.

- Említene pár sikertörténetet a pályájáról?

- A kérdező maga is egy sikertörténet számomra. Akik legalább eljutottak arra a szintre, hogy megtanultak bottal közlekedni zömében megtalálták a boldogságukat. A foglalkoztatottjaink életút követése és visszajelzéseik alapján minden gyermek és fiatal társadalmi integrációja sikeres volt. $80 \%$ a felsőoktatásban tovább tanulók aránya. A munka világába történö bekapcsolódás a végzettségnek megfelelő munkakör megtalálása zökkenőmentesen alakult. Büszkeségeink között említhetünk olyan személyt, aki a Magyar Operaház kórusának tagja, olyat, aki paraolimpiai világbajnoki bronzérmes kajakban, úszásban aranyérmet nyert. Jogi pályára készülőt, valamint a média világában tevékenykedőt. Ez csak néhány említésre méltó példa a sok közül a teljesség igénye nélkül.

- Tehát, aki két bottal közlekedik, annak jobbak az esélyei a sikeres éltre, mint egy kerekes székesnek?

- Általában igen. A tapasztalatom szerint ez a személytől is függ, mennyire képes és mennyire akar a társadalomba integrálódni.

- Végezetül evezzünk kicsit nemzetközi vizekre, hiszen a Petö Módszert nemcsak itthon, hanem számos külföldi országban alkalmazzák. Említene olyan országokat, ahol elöszeretettel alkalmazzák a mozgássérültek fejlesztésére?

- Módszereinkre legelöször az Egyesült Királyság figyelt fel.1994-től Norvégiában, ezt követően 1998-tól, pedig Grand Rapids-ban jött létre egy újabb képzési és fejlesztési helyszín az Amerikai Egyesült Államokban. Az 1998 év nagyon termékenynek mondható, mert 
Amerika mellett ekkor létesült kapcsolat Spanyolországgal, és Ausztriával is. Spanyolországban elöször Navarrában, majd 2002-től Pamplonában létesült konduktív nevelési központ. 2001-től a német szülők kezdeményezésére Ulmban jött létre egy helyi Pető Intézet. 2003-ban Romával 2007-ben pedig Moszkvával bővült a nemzetközi hálózatunk.

- Köszönöm szépen az interjút!

Interjúalany: F.T.

\section{Melléklet:}

Készítette: Oravecz Adrienn

Helyszín: Skype Internetes beszélgetés, Svédország

Interjú időpontja: 2015.10.31.

- Beszélgetésünk a Svédországi Petö intézetröl fogunkszól. Hogy került Svédországba? Miért ezt választotta?

- 2004-ben végeztem a Pető Intézetben. Ebben az évben az intézet nem vett föl a frissen végzettek közül újabb konduktorokat, így megnéztem a nemzetközi álláslehetőségeket... Valami teljesen újra vágytam, így esett a választásom Svédországra.

- Milyen nehézségekkel, kihívásokkal nézett szembe az elején?

- Egyedül vágtam bele az ismeretlenbe, így eleinte nagyon hiányzott a családom. Másik nehézség volt számomra, hogy bár folyékonyan beszélek angolul a gyerekekkel való kommunikáció svédül történt. Magamtól, otthon, munka után, nyelvkönyvekből sajátítottam el a svéd nyelvet. A három hónapos próbaidőszak végére el kellett jutnom olyan nyelvi szintre svédből, hogy viszonylag jól meg tudjam magam értetni, és kommunikálni tudjak a gyerekkel. Mivel ezt a követelményt sikeresen teljesítettem a próbaidőszak végén állandó szerződést kaptam.

- Milyen típusú nevelésben részesülnek a neveltek? Intervallum? Folyamatos? Utógondozásos forma?

- Eleinte csak intervallumneveléssel foglalkozott a cég. Négyhetes időtartalomra jöttek a gyerekek a szüleikkel együtt. Mivel ez az időtartalom nem sok, nagyon nagy figyelmet fordítunk a csoportok összetételére, hogy hasonló állapotú és életkorú gyerekek kerüljenek egy csoportba. Svédországban a sérült gyerekek személyi asszisztenst kaphatnak, aki a „gyerekek” meghosszabbított keze, aki nem kiszolgáló személyzet, de segítségére van a napi önellátási tevékenységek elvégzésében. Egy- egy ilyen fejlesztési periódus után mindig készítünk egy a 
foglalkozást részletesen leíró és az ez idő alatt elért fejlődési eredményeket, bemutató dokumentumot, amely természetesen megfelel a svéd egészségügyi szabályzat követelményeinek. Nagyon pontosan kell végeznünk a dokumentációt, mert csak azok a fejlesztési formák kapnak állami, illetve megyei támogatást, amelyeknek a hatékonysága bizonyított. A kezdetek kezdetén 1997-ben nagyon csekély volt a konduktív pedagógia, mint mozgásfejlesztési forma támogatottsága, de mára az egyik leginkább támogatott rehabilitációs forma, mert az eredményeink magukért beszélnek.

- Szóval Petö András módszere népszerü és elfogadott itt?

- Igen abszolút.

- Hány konduktor dolgozik itt jelenleg?

- A létszám harminc fölött van és a közeljövőben még tovább fog nőni, mert jövő ősszel, nyílik általános és középiskolánk Stockholmban.

- Meséljen a csoportokról. Összetétel, gyerekek diagnózisa, hasonlóságok és különbségek stb.

- Átlagosan hat gyermek van egy csoportba, de van egy íratlan szabályunk, ha már négy gyermek van a csoportba, akkor két konduktor együtt vezeti a fejlesztő programot. Különbség a magyarországi rendszerhez képest, hogy itt mindenben a szülö dönt, a konduktor vagy az orvos javaslatot tehet. A gyerekeknek is nagyobb beleszólása van, mint otthon Magyarországon, mert itt a szülö a gyermeket is bevonja folyamatba és megkérdezi, hogy ö mit szeretne elérni ebben a négyhétben. Különbség a magyarországi programhoz képest például, hogy gyakrabban dolgoztatjuk a növendékeinket szőnyegen, mint priccsen, mivel az otthonhoz hasonló körülményekben történő tréning sokban segít a családoknak az otthoni folytatásban. Az, hogy mennyi a napi foglalkozás időtartalma szintén a megyei döntésszabályozástól függ. Például: Malmöben és Gotheborgban öt naposak a hetek. Általában itt Gotheborgban négy órában tréningezünk, azok jönnek két órás fejlesztésre, akik nagyon jó állapotban vannak vagy épp az ellentettje. Az első tréningesek, és a pici babák szintén két órás konduktív programban vesznek részt. Két órás csoportokban van tízórai, és ott törekszünk a helyes étrend kialakítására, az evőeszközök helyes használatának megtanítására. Stockholmban a szerződésünk három órás fejlesztést engedélyez és elöírja, hogy a kezelés után bizonyos idő elteltével vissza kell jönnie a gondozottnak egy napra konzultációra. Az életkori eloszlás rendkívül változatos, mert öt hónapos csecsemőtől egészen az aggastyánokig vannak pácienseink. Az iskolába készülő gyerekeknek tartunk grafo-motoros fejlesztést is, ennek a fontosságát még a szülökben sokszor tudatosítanunk kell. A legtöbb betegünknek a központi idegrendszere sérült, vannak olyanok is, akik CP-hez hasonló tünetekkel rendelkeznek. Van szerződésünk a nyitott gerinccel születettek ellátására is, ám ennek a betegségcsoportnak az elöfordulása alacsony az intézetünkben. Sok a fiatal stroke-os betegünk, akik semmilyen anyagi hozzájárulásban nem részesülnek, maguk fizetik a fejlesztést. Számukra négy napos három órás kezelést nyújtunk leginkább, ami jó eredményt hoz, de sem, időben sem anyagilag nem akkora megterhelés, mint egy négy hetes kurzus.

- Milyen a fejlesztôterem felszereltsége?

- A fejlesztőterem felszereltsége hasonló a magyarországihoz, mert petős bútorokat használunk. Termeink tágasak és világosak. A cég privát üzemeltetésü, a tulajdonos maga is konduktor, ami nagy előny, mert ha valamilyen fejlesztőeszközre van szükségem a napi munkám hatékonyságának növeléséhez, megérti a szükségességét, nem kell hosszas indoklás. Fontos az eszközállomány folyamatos frissítése, mert ezek a hatékony munkához elengedhetetlenek, de az is fontos, hogy olyan eszközökkel dolgozzunk, amik a szülök számára is könnyen beszerezhetők, hogy otthon folytatódhasson az itt elkezdett fejlesztés. 
KÜLÖNLEGES BÁNÁSMÓD, I. ÉVF. 2015/4.

- Milyen a munkahelyi légkör?

- Nagyon személyközpontú a légkör. Fontos a vezetöségnek, hogy mi konduktorként elégedettek legyünk a munkakörülményeinkkel, hiszen akkor hatékonyabban és magasabb színvonalon tudjuk segíteni a ránk bízott pácienseket. A munkánkat anyagilag is jobban honorálják. Sok csapatépítő programot szerveznek számunkra, mert fontos a kollegális összetartás, egymás szakmai támogatása.

- Említette a szervezeti hálózat bővülését...

- Igen. Dinamikus fejlődésünknek ékes bizonyítéka, hogy Gotheborgban van kisegítő általános és középiskolánk. Van általános iskolánk Malmöben és jövő ősszel, nyílik általános és középiskolánk Stockholmban. Az iskolai fejlesztés és a konduktív teljesen egymásba van integrálva. Például: Hason fekve a fekvő alatt számokkal dolgozunk az egyén képességeinek megfelelően. Lehet, hogy az egyik gyerek a tízes számkörben, míg a másik a százasban old meg feladatokat. Mindezt tartásjavító helyzetekben és feladatok megoldása közben. Projekt módszerrel dolgozzák fel a tananyagot, az egyéni képességeikhez mérten a nekik megfelelő tempóban. Kis osztálylétszámmal dolgozunk általában ötfős, egy- egy osztály. Az oktatást is konduktorok végzik, mert amikor én végeztem tanítói képesítés is járt a diploma mellé. 